Article

\title{
Impact of Trade and Financial Globalization on Renewable Energy in EU Transition Economies: A Bootstrap Panel Granger Causality Test
}

\author{
Yilmaz Bayar ${ }^{1}\left(\mathbb{D}\right.$, Mahmut Unsal Sasmaz $^{2}\left(\mathbb{D}\right.$ and Mehmet Hilmi Ozkaya ${ }^{2, *}$ \\ 1 Faculty of Economics and Administrative Sciences, Bandirma Onyedi Eylul University, \\ Bandirma/Balikesir 102000, Turkey; yilmazbayar@yahoo.com \\ 2 Faculty of Economics and Administrative Sciences, Usak University, Usak 64000, Turkey; \\ mahmut.sasmaz@usak.edu.tr \\ * Correspondence: mehmethilmi.ozkaya@usak.edu.tr; Tel.: +90-506-307-2468
}

Citation: Bayar, Y.; Sasmaz, M.U.; Ozkaya, M.H. Impact of Trade and Financial Globalization on Renewable Energy in EU Transition Economies: A Bootstrap Panel Granger Causality Test. Energies 2021, 14, 19. https: //dx.doi.org/10.3390/en14010019

Received: 27 November 2020 Accepted: 18 December 2020 Published: 22 December 2020

Publisher's Note: MDPI stays neutral with regard to jurisdictional claims in published maps and institutional affiliations.

Copyright: () 2020 by the authors. Licensee MDPI, Basel, Switzerland. This article is an open access article distributed under the terms and conditions of the Creative Commons Attribution (CC BY) license (https: / creativecommons.org/ licenses/by/4.0/).

\begin{abstract}
The globalized world has experienced significant environmental degradation together with raising global production and population. In this context, the employment of renewable energy use has become crucial for a sustainable environment and development. In the research, the mutual causality among renewable energy, trade and financial globalization, real GDP per capita, and $\mathrm{CO}_{2}$ emissions in EU transition economies experiencing the integration with global economy was explored through bootstrap panel Granger causality test for the period of 1995-2015. The causality analysis revealed a unilateral causality from trade globalization to renewable energy in Estonia, Latvia, and Slovenia, and from renewable energy to trade globalization in Croatia and Lithuania. However, no significant causality between financial globalization and renewable energy was revealed. On the other side, a unilateral causality from $\mathrm{CO}_{2}$ emissions to renewable energy in Lithuania and Slovenia, and from renewable energy to $\mathrm{CO}_{2}$ emissions in Czechia, Hungary, and Latvia and a reciprocal causality between renewable energy to $\mathrm{CO}_{2}$ emissions in Romania and Slovakia and a unilateral causality from real GDP per capita to renewable energy in Czechia, Romania, and Slovenia was discovered in the causality analysis.
\end{abstract}

Keywords: trade globalization; financial globalization; $\mathrm{CO}_{2}$ emissions; real GDP per capita; renewable energy; bootstrap panel Granger causality; EU transition economies

\section{Introduction}

Global production has increased considerably as of the Industrial Revolution. In turn, energy requirements have also increased considerably. The considerable increases in fossil fuel consumption have been experienced due to global production and population growth. However, sustainable economic development, environmental sustainability and health problems have accompanied the rising consumption of fossil fuels [1-3]. The aforementioned developments have directed countries towards renewable energy production regarding its sustainability and clean energy properties.

Renewable energy is a sustainable, replenishable and less carbon-intensive energy type derived from sources like wind, solar, hydropower, geothermal, bioenergy, and the ocean [4]. Although renewable energy production requires a high amount of investment and technology, countries have turned to renewable energy production. Thus the global renewable power production raised to 25.01 exajoules in 2019 from 0.18 exajoules in 1965 [5]. In this context, scholars and policy-makers have tended to explore the factors underlying renewable energy production. The studies have revealed real GDP per capita, financial openness, foreign direct investment inflows, trade openness, energy prices, stock market returns, energy dependence, human development, democracy, population, $\mathrm{CO}_{2}$ emissions as the institutional, demographic and economic factors underlying the renewable energy [6-11]. 
The related empirical literature reveals that a few scholars had studied the influence of trade and financial globalization on renewable energy. However, both trade and financial globalization can contribute to renewable energy production and consumption through increases in production, technological transfer and financing provision. The study aims to contribute to the limited literature considering the gap in the relevant literature. In this regard, the paper aims to analyze the causality among trade and financial globalization, renewable energy, $\mathrm{CO}_{2}$ emissions, real GDP per capita in the sample of eleven EU transition states during the period 1995-2015 through Kónya [12] causality test. The EU transition economies have begun to integrate with the global economy through an institutional and economic transformation as of the late 1980s. Furthermore, the EU transition economies experienced significant increases in share of energy from renewable sources in total energy as seen in Table 1. Therefore, we explore the causality between economic globalization indicators and renewable energy in sample of EU transition economies.

Table 1. Share of energy from renewable sources in total energy (\%).

\begin{tabular}{cccc}
\hline Country & $\begin{array}{c}\mathbf{1 9 9 0} \text { (World Bank, } \\
\mathbf{2 0 2 0 a})\end{array}$ & 2009 (Eurostat, 2020) & 2018 (Eurostat, 2020) \\
\hline Bulgaria & 1.91684851 & 12.005 & 20.528 \\
\hline Croatia & 21.9231797 & 23.597 & 28.024 \\
\hline Czechia & 3.57150703 & 9.978 & 15.15 \\
\hline Estonia & 3.35607862 & 22.931 & 29.996 \\
\hline Hungary & 3.85666956 & 11.674 & 12.489 \\
\hline Latvia & 17.5696905 & 34.318 & 40.292 \\
\hline Lithuania & 3.09677851 & 19.798 & 24.448 \\
\hline Poland & 2.50148484 & 8.661 & 11.284 \\
\hline Romania & 3.35576588 & 22.157 & 23.875 \\
\hline Slovakia & 2.22533593 & 9.368 & 21.149 \\
\hline Slovenia & 12.3519506 & 20.147 & \\
\hline
\end{tabular}

Source: Eurostat [13] and World Bank [14].

The paper's remaining sections are structured as follows: the next part briefly summarizes the related literature, the third part introduces the dataset and the methodological approach, and the fourth section conducts the applied analysis and the study ends up with the conclusions.

\section{Literature Review}

Renewable energy has become a significant energy source for a sustainable environment and development. Therefore, the determinants of renewable energy production have been widely explored in energy and environment economics. The related empirical literature has generally remained inconclusive, in other words, have reached mixed findings about the impact of institutional and economic variables on renewable energy for different country groups. We evaluate that this can mainly result from the use of samples with different characteristics and methods. Furthermore, the world experienced a considerable improvement in the globalization process. Most of the countries have integrated with global markets and can benefit from the positive aspects of globalization. However, a few researchers have centered on the interaction between globalization, economic globalization, and renewable energy. The scholars have generally used the globalization index in the limited relevant empirical literature, although globalization is a multifaceted process. This research focuses on trade and financial globalization on $\mathrm{CO}_{2}$ emissions, considering the aforementioned issues.

In the literature about the impact of globalization on $\mathrm{CO}_{2}$ emissions, Leitão [15] and Yazdi and Shakouri [16] found a reciprocal causality between globalization and renewable 
energy. However, Padhan et al. [17] revealed a negative influence of economic globalization on renewable energy consumption, but Gozgor et al. [18] discovered a positive influence of economic globalization on renewable energy.

In this context, Leitão [15] analyzed the causality among globalization, $\mathrm{CO}_{2}$ emissions, economic growth, and renewable energy in Portugal during the period 1970-2010 and discovered a reciprocal causality between globalization and renewable energy. On the other hand, Yazdi and Shakouri [16] researched the causality among globalization, trade openness, economic growth, and renewable energy consumption in Iran for the period of 1992-2014 through ARDL cointegration test and revealed a reciprocal causality between globalization, renewable energy consumption, and economic growth.

Padhan et al. [17] researched the effect economic globalization and economic growth on renewable energy consumption in OECD member states through quantile regression for the period of 1970-2015 and revealed a negative influence of economic globalization on renewable energy consumption, but a positive influence of real GDP per capita on renewable energy consumption. However, Gozgor et al. [18] reached the opposite conclusion for the nexus of economic globalization and renewable energy in the same sample through cointegration analysis.

In the empirical literature, the relationship between trade liberalization/trade and renewable energy has been explored and different causality directions between two variables have been revealed for the different countries. In this context, Sebri et al. [19] explored the interaction among trade openness, $\mathrm{CO}_{2}$ emissions, economic growth, and renewable energy consumption in BRICS countries for the duration of 1971-2010 through VECM and a mutual causality between economic growth and renewable energy was discovered. On the other side, Rasoulinezhad and Saboori [9] explored the relationship among financial and trade openness, $\mathrm{CO}_{2}$ emissions, economic growth, and renewable energy consumption in Commonwealth of Independent States over the 1992-2015 period through causality analysis and no significant causality between trade liberalization and renewable energy consumption, but a unilateral causality from financial openness to renewable energy consumption and a bilateral causality between renewable energy and economic growth was discovered.

Jebli et al. [20] explored the causality among trade openness, $\mathrm{CO}_{2}$ emissions, economic growth, and renewable energy consumption in 22 Central and Southern American economies throughout 1995-2010 through panel VECM Granger causality and a unilateral causality from renewable energy to trade openness, $\mathrm{CO}_{2}$ emissions, and economic growth was revealed in the short run, but a bilateral causality among renewable energy, trade openness, and $\mathrm{CO}_{2}$ emissions in the long run. Zeren and Akkuş [21] examined the causality between trade openness, renewable energy consumption in top Bloomberg emerging economies over 1980-2015 period through the Dumitrescu and Hurlin [22] panel causality test and a mutual causality between trade liberalization and renewable energy was discovered.

On the other side, Murshed [23] researched the influence of trade openness on renewable energy consumption in South Asian Economies for 2000-2017 through causality and regression analyses and discovered that trade openness enhanced renewable energy consumption. Akar [24] reached a similar finding for Balkan countries. Alam and Murad [25] explored the influence of trade openness, economic growth on renewable energy consumption in 25 OECD states over 1970-2012 period through panel ARDL. They discovered a positive influence of trade liberalization and economic growth on renewable energy consumption. However, Lau et al. [26], Kumaran et al. [27], and Zhao et al. [28] reached conclusions suggesting a negative impact of trade openness on renewable energy.

Furthermore, some researchers have explored the influence of total trade or foreign trade volume on renewable energy. In this context, Aïssa et al. [29] researched the interaction among renewable energy consumption, trade, and output in eleven African countries through panel cointegration analysis. They revealed a positive long-run effect of trade on renewable energy, but no causality between renewable energy consumption and trade or 
output. Kim and Kim [30] also explored the relationship between renewable energy and international trade and discovered a positive effect of international trade on renewable energy. Jebli and Youssef [31] also conducted research on the mutual interaction among foreign trade, $\mathrm{CO}_{2}$ emissions, economic growth, and renewable energy consumption in Tunisia over 1980-2009 period through causality analysis and a unilateral causality from trade, GDP, $\mathrm{CO}_{2}$ emissions, to renewable energy has been discovered.

Jebli et al. [32] researched the interaction between trade and renewable energy in OECD member states over the duration of 1980-2010 and a unilateral causality from trade to renewable energy was discovered. Tiba et al. [33] also analyzed the interaction among foreign trade, renewable energy, environment, and economic growth in 24 middle and high income countries and a unilateral causality from foreign trade to renewable energy, a mutual causality between $\mathrm{CO}_{2}$ emissions and economic growth, between $\mathrm{CO}_{2}$ emissions and renewable energy was discovered in high income countries. Furthermore, a mutual causality between trade/economic growth and renewable energy was discovered in middle-income countries.

Amri [34] explored the relationship among trade, economic growth, and renewable energy in 72 developed and developing countries for the duration of 1990-2012 through dynamic regression analysis and found a mutual causality between trade/income and renewable energy consumption. Liu et al. [35] analyzed the interaction among renewable energy, trade, and output in 15 Asia-Pacific countries over 1994-2014 period through cointegration and causality analyses and a unilateral short run causality from import to renewable energy and output and a mutual causality between renewable energy and output and a unilateral causality from international trade to renewable energy was discovered. Nathaniel and Khan [36] explored the interaction among trade, renewable energy, and ecological footprint in ASEAN countries for the period of 1990-2016 through cointegration and causality analyses, and no significant causality between trade and renewable energy was discovered.

The studies on the impact of GDP per capita and economic growth on renewable energy have reached mixed findings.

Alabi et al. [37] explored the causal interaction between economic growth and renewable energy consumption in Angola, Algeria, and Nigeria over the 1971-2011 period and disclosed a bi-lateral causality between two variables. Caruso et al. [38] reached similar findings for selected EU countries. However, Menyah et al. [39], Ocal and Aslan [40], and Bakirtas et al. [41] reached a significant causality from economic growth to renewable energy.

On the other side, Lin et al. [42] researched the determinants of the renewable electricity share in total electricity consumption in China for the 1980-2011 period and revealed a positive influence of economic growth on renewable electricity consumption. Lau et al. [26] researched the determinants of renewable energy consumption in Malaysia over the 19802015 period through ARDL approach and disclosed a positive influence of economic growth on renewable energy. Przychodzen and Przychodzen [43] explored the determinants of renewable energy consumption in 27 transition economies for the period of 1990-2014 and economic growth positively affected renewable energy production.

However, Mehrara et al. [44] explored the factors underlying renewable energy use in Economic Cooperation Organization countries during the period 1992-2011 and revealed a negative impact of economic growth on renewable energy use. Omoju [45] reached the same findings for China. Akar [24] explored the determinants of renewable energy in Balkan countries over the 1998-2011 period through regression analysis and disclosed a negative effect of economic growth on renewable energy consumption. Ergun et al. [10] researched the determinants of renewable energy consumption in Africa from 1990 to 2013 through regression analysis and revealed a negative impact of gross domestic product per capita on renewable energy production.

Some scholars explored the interaction between $\mathrm{CO}_{2}$ emissions and renewable energy consumption and mainly revealed a positive impact of $\mathrm{CO}_{2}$ emissions on renewable 
energy. In this context, Omri and Nguyen [46] researched the impact of $\mathrm{CO}_{2}$ emissions on renewable energy consumption in 64 countries during the 1990-2011 period through regression analysis and reached a positive impact of $\mathrm{CO}_{2}$ emissions on renewable energy consumption. On the other side, Dogan and Seker [47] explored the determinants of $\mathrm{CO}_{2}$ emissions in the EU and revealed a bilateral causality between $\mathrm{CO}_{2}$ emissions and renewable energy.

Omri et al. [48] analyzed the determinants of renewable energy consumption in 64 countries through regression analysis and revealed the $\mathrm{CO}_{2}$ emissions as a significant driver of renewable energy consumption. However, Paweenawat and Plyngam [49] researched the causality among $\mathrm{CO}_{2}$ emissions, energy consumption, income, and renewable energy in Thailand over the 1986-2012 period through ARDL approach. They revealed no significant causality between $\mathrm{CO}_{2}$ emissions and renewable energy in the short run.

\section{Data and Econometric Methodology}

The study explores the causal interaction among renewable energy, trade globalization, financial globalization, $\mathrm{CO}_{2}$ emission, and real GDP per capita in EU transition economies for the duration of 1995-2015. Renewable energy is proxied by share of energy from renewable sources, trade globalization and financial globalization are respectively represented by indexes of trade globalization and financial globalization calculated on an annual basis by [50]. Trade globalization index is calculated based on exports and imports of goods and services, trade regulations, trade partner diversity, trade agreements, trade taxes, and tariffs. On the other side, the financial globalization index is calculated based on international investments in foreign direct investments, portfolio investments, international debt, international income payments, international reserves, international investment agreements, investment restrictions, and capital account openness [51]. Real GDP per capita is proxied by GDP per capita (constant 2010 US\$) and $\mathrm{CO}_{2}$ emissions are represented by $\mathrm{CO}_{2}$ emissions (metric tons per capita) as seen in Table 2. The renewable energy data existed for the period of 1990-2015 in the database of World Bank and the period of 2009-2018 in Eurostat database. Therefore, the study period was specified as 1995-2015 regarding World Bank data [14] and all the variables were annual.

Table 2. Dataset definition.

\begin{tabular}{|c|c|c|}
\hline Variables & Definition & Source \\
\hline RNW & $\begin{array}{l}\text { Share of energy from } \\
\text { renewable sources (\%) }\end{array}$ & World Bank [14] \\
\hline TRGI & Trade globalization index & KOF Swiss Economic Institute [50] \\
\hline FINGI & Financial globalization index & KOF Swiss Economic Institute [50] \\
\hline GDP & $\begin{array}{c}\text { GDP per capita (constant } 2010 \\
\text { US\$) }\end{array}$ & World Bank [52] \\
\hline $\mathrm{CO}$ & $\begin{array}{l}\mathrm{CO}_{2} \text { emissions (metric tons } \\
\text { per capita) }\end{array}$ & World Bank [53] \\
\hline
\end{tabular}

The study sample consists of eleven transition states of EU. The programs Gauss 10.0 (APTECH Systems, Higley, Arizona, USA), EViews 10.0 (HIS Global, Irvine, California, USA), and Stata 14.0 (StataCorp LLC, TA, USA) were used for the empirical analysis. The average share of energy from renewable sources of the sample in the study duration was $16.35 \%$. The average of trade and financial globalization indexes in the sample were 73.76 and 65.63 , but three variables considerably varied among the cross-sections. On the other side, the average of real GDP per capita was 12,097 USD, but it varied very considerably among the countries. Lastly, the average $\mathrm{CO}_{2}$ emissions were about 6.75 metric tons per capita as seen in Table 3. 
Table 3. Main characteristics of the series.

\begin{tabular}{ccccc}
\hline Variables & Mean & Std. Dev. & Min & Max \\
\hline RNW & 16.34636 & 9.542929 & 3.106707 & 40.36562 \\
\hline TRGI & 73.76266 & 10.54052 & 42.95188 & 91.06991 \\
\hline FINGI & 65.6343 & 12.83061 & 33.496 & 87.16071 \\
\hline GDP & 12097.59 & 4950.488 & 3784.204 & 25430.35 \\
\hline CO & 6.755519 & 2.850889 & 2.682623 & 14.66803 \\
\hline
\end{tabular}

In a selection of the panel causality tests, the presence of cross-sectional dependency and heterogeneity in the panel exhibits importance to obtain relatively more reliable results. In this context, disregarding the cross-sectional dependence would probably produce size and bias distortions in the analyses [54,55]. Furthermore, seemingly unrelated regression (SUR) would exceed ordinary least squares (OLS) by estimating the equation sets one by one [56] and in turn transforms the model in a way that the error terms become uncorrelated [56]. On the other side, the slope coefficients' heterogeneity is essential for causality analysis. The causality between two series by putting the panel's joint constraint is a robust null hypothesis [57]. Homogeneity presumption for panel parameters cannot include heterogeneity among the countries because of country-specific features [58].

In the pretests, the presence of cross-sectional dependency and heterogeneity for the series was discovered. Therefore, we investigated the causal interaction among the series through Kónya [12] bootstrap panel Granger causality test regarding cross-sectional dependency and heterogeneity. Konya [12] bootstrap causality test rests on SUR and critical values are calculated for each cross-section through bootstrapping. Therefore, stationarity of the series is not required and Granger causality test can be employed for each country in the panel through Konya [12] causality test. The test rests on the following SUR estimation of two equation sets:

$$
\begin{gathered}
y_{i, t}=\alpha_{1,1}+\sum_{i=1}^{t y_{1}} \beta_{1,1, i} y_{1, t-i}+\sum_{i=1}^{l x_{1}} \gamma_{1,1, i} \chi_{1, t-i}+\varepsilon_{1,1, t} \\
y_{2, t}=\alpha_{1,2}+\sum_{i=1}^{l y_{1}} \beta_{1,2, i} y_{2, t-i}+\sum_{i=1}^{l x_{1}} \gamma_{1,2, i} \chi_{2, t-i}+\varepsilon_{1,2, t} \\
y_{N, t}=\alpha_{1, N}+\sum_{i=1}^{l y_{1}} \beta_{1, N, i} y_{N, t-i}+\sum_{i=1}^{l x_{1}} \gamma_{1, N, i} \chi_{N, t-i}+\varepsilon_{1, N, t}
\end{gathered}
$$

and:

$$
\begin{gathered}
\chi_{1, t}=\alpha_{2,1}+\sum_{i=1}^{l y_{2}} \beta_{2,1, i} y_{1, t-i}+\sum_{i=1}^{l x_{2}} \gamma_{2,1, i} \chi_{1, t-i}+\varepsilon_{2,1, t} \\
\chi_{2, t}=\alpha_{2,2}+\sum_{i=1}^{l y_{2}} \beta_{2,2, i} y_{2, t-i}+\sum_{i=1}^{l x_{2}} \gamma_{2,2, i} \chi_{2, t-i}+\varepsilon_{2,2, t} \\
\chi_{N, t}=\alpha_{2, N}+\sum_{i=1}^{l y_{2}} \beta_{2, N, i} y_{N, t-i}+\sum_{i=1}^{l x_{2}} \gamma_{2, N, i} \chi_{N, t-i}+\varepsilon_{2, N, t}
\end{gathered}
$$

where the renewable energy is proxied $y$, trade globalization index is proxied by $x$ in system $1 ; y$ denotes the renewable energy, $x$ denotes the financial globalization index in system 2; $y$ denotes the renewable energy, $x$ denotes the $\mathrm{CO}_{2}$ emissions in system 3; $y$ denotes the renewable energy, $x$ denotes the real GDP per capita in system $4 . l$ is the length. In this context, a unilateral significant causality from $x$ to $y$ is revealed if not all the $\gamma_{1, j, i} \mathrm{~s}$ are zero, but all $\beta_{2, j, i}$ s are zero. On the other side, a significant unilateral causality from $y$ to $x$ is revealed if all $\gamma_{1, j, i}$ s are zero, but not all $\beta_{2, j, i}$ s are zero. Furthermore, a reciprocal 
significant causality between $\mathrm{x}$ and $\mathrm{y}$ is revealed if neither $\gamma_{1, j, i}$ s nor $\beta_{2, j, i}$ s are zero. Lastly, no significant causality between $x$ and $y$ is revealed if all $\gamma_{1, j, i} s$ and $\beta_{2, j, i}$ s are zero.

\section{Empirical Analysis}

In the empirical analysis part of the study, first presence of cross-sectional dependency and heterogeneity were explored through relevant econometric tests. For this reason, the cross-sectional dependency test of LM, LM CD, and $\mathrm{LM}_{\mathrm{adj}}$.), which are respectively developed by [59-61] were conducted to question the cross-section independence, and the test results were introduced in Table 4 . The null hypothesis $\left(\mathrm{H}_{0}=\right.$ cross-sectional independence) declined at a 5\% significance level, and cross-sectional dependency among the series was discovered.

Table 4. Cross-sectional dependence tests' results.

\begin{tabular}{ccc}
\hline Test & Test Statistic & Prob. \\
\hline LM & 76.23 & 0.0306 \\
\hline LM adj $^{*}$ & 2.381 & 0.0173 \\
\hline LM CD $^{*}$ & 4.248 & 0.0000 \\
\hline${ }^{*}$ two-sided test. & &
\end{tabular}

The homogeneity presence was explored through [62] homogeneity tests, and the results were introduced in Table 5. The null hypothesis asserting the presence of homogeneity was declined at $1 \%$ significance level, and the existence of heterogeneity was discovered. The results of both tests directed us to employ a causality test regarding cross-sectional dependency and heterogeneity.

Table 5. Homogeneity tests' results.

\begin{tabular}{ccc}
\hline Test & Test Statistic & Prob. \\
\hline$\widetilde{\Delta}$ & 9.015 & 0.000 \\
\hline$\widetilde{\Delta}_{\text {adj. }}$ & 10.571 & 0.000 \\
\hline
\end{tabular}

The causal interaction among renewable energy, trade globalization, financial globalization, $\mathrm{CO}_{2}$ emissions, and real GDP per capita in eleven EU transition economies for 1995-2015 was explored through bootstrap causality test and test results reported in Tables 6-9. The causality analysis between trade globalization and renewable energy presented in Table 6 and a unilateral causality from trade globalization to renewable energy in Estonia, Latvia, and Slovenia, and unilateral causality from renewable energy to trade globalization in Croatia and Lithuania was discovered. In theoretical terms, a significant causality between trade globalization and renewable energy is expected, considering the increases in the output and technological transfer resulting from trade globalization. Still, the causality direction can be changed depending on the countries' potential and approach towards renewable energy. In this context, Aïssa et al. [29], Rasoulinezhad and Saboori [9], and Nathaniel and Khan [36] revealed no significant causality between trade and renewable energy, but Sebri et al. [19], Amri [34], and Zeren and Akkuş [21] discovered a two-way causality between two variables. On the other side, Jebli and Youssef [31], Jebli et al. [32], Tiba et al. [33], and Liu et al. [35] revealed a unilateral causality from trade to renewable energy. Still, Jebli et al. [20] showed a unilateral causality from renewable energy to trade. Our findings revealed that trade globalization had a significant effect on the renewable energy in Estonia, Latvia, and Slovenia incompatible with Jebli and Youssef [31], Jebli et al. [32], Tiba et al. [33], and Liu et al. [35]. On the other side, a significant causality from renewable energy to trade globalization was revealed in Croatia and Lithuania incompatible with Jebli et al. [20]. 
Table 6. Causality analysis between renewable energy and trade globalization.

\begin{tabular}{|c|c|c|c|c|c|c|c|c|}
\hline \multirow{3}{*}{ Countries } & \multicolumn{4}{|c|}{$\mathrm{H}_{0}$ : TRGI Is Not the Cause of RNW } & \multicolumn{4}{|c|}{$\mathrm{H}_{0}: \mathrm{RNW}$ Is Not the Cause of TRGI } \\
\hline & \multirow{2}{*}{ Wald St. } & \multicolumn{3}{|c|}{ Bootstrap Critic Value } & \multirow{2}{*}{ Wald St. } & \multicolumn{3}{|c|}{ Bootstrap Critic Values } \\
\hline & & $1 \%$ & $5 \%$ & $10 \%$ & & $1 \%$ & $5 \%$ & $10 \%$ \\
\hline Bulgaria & 8.8464 & 44.7627 & 24.2052 & 17.1286 & 7.3971 & 32.0311 & 16.2259 & 10.7983 \\
\hline Croatia & 0.4123 & 32.8062 & 15.8140 & 10.7433 & $34.8960 * *$ & 37.9527 & 19.3220 & 12.9013 \\
\hline Czechia & 0.7446 & 42.9621 & 20.6403 & 14.3989 & 5.4331 & 44.3254 & 23.2376 & 15.5162 \\
\hline Estonia & 12.9861 * & 35.4443 & 17.5990 & 11.6910 & 0.1451 & 30.4781 & 15.2729 & 10.5094 \\
\hline Hungary & 7.8702 & 6.9005 & 26.1133 & 18.9257 & 0.1856 & 44.7453 & 22.4945 & 15.2530 \\
\hline Latvia & $16.3657^{* *}$ & 22.5088 & 12.3336 & 8.2503 & 0.1588 & 35.5174 & 18.4655 & 12.3581 \\
\hline Lithuania & 1.8563 & 40.3328 & 20.7102 & 14.1074 & $27.2157^{* *}$ & 30.5951 & 16.2497 & 11.0971 \\
\hline Poland & 7.0130 & 55.5188 & 30.9381 & 22.0181 & 9.2569 & 47.9452 & 24.0374 & 16.7736 \\
\hline Romania & 4.8904 & 32.9063 & 17.7028 & 12.0731 & 4.3656 & 42.0022 & 20.0110 & 13.4153 \\
\hline Slovakia & 7.4813 & 45.3693 & 23.6163 & 16.0807 & 0.2603 & 40.0041 & 21.8501 & 15.0193 \\
\hline Slovenia & 13.3336 * & 36.0687 & 17.6316 & 12.1915 & 3.9083 & 39.0535 & 19.7149 & 13.3175 \\
\hline
\end{tabular}

$* *, *$ indicates that it is respectively significant at $5 \%, 10 \%$.

Table 7. Causality analysis between renewable energy and financial globalization.

\begin{tabular}{|c|c|c|c|c|c|c|c|c|}
\hline \multirow{3}{*}{ Countries } & \multicolumn{4}{|c|}{$\mathrm{H}_{0}$ : FINGI Is Not the Cause of RNW } & \multicolumn{4}{|c|}{$\mathrm{H}_{0}: \mathrm{RNW}$ Is Not the Cause of FINGI } \\
\hline & \multirow{2}{*}{ Wald St. } & \multicolumn{3}{|c|}{ Bootstrap Critic Value } & \multirow{2}{*}{ Wald St. } & \multicolumn{3}{|c|}{ Bootstrap Critic Value } \\
\hline & & $1 \%$ & $5 \%$ & $10 \%$ & & $1 \%$ & $5 \%$ & $10 \%$ \\
\hline Bulgaria & 2.4116 & 41.7844 & 22.5821 & 5.4261 & 1.6362 & 32.3546 & 16.4587 & 11.0447 \\
\hline Croatia & 0.3166 & 29.4784 & 15.6118 & 10.7328 & 0.3302 & 41.3339 & 21.2784 & 14.4160 \\
\hline Czechia & 6.0159 & 30.6188 & 15.7428 & 10.8004 & 4.3581 & 34.3406 & 18.8492 & 12.7182 \\
\hline Estonia & 0.4498 & 27.8959 & 13.8942 & 9.5116 & 0.9312 & 39.6911 & 20.1473 & 13.6960 \\
\hline Hungary & 7.8604 & 37.6044 & 20.2577 & 14.3526 & 7.7433 & 36.3349 & 18.9620 & 12.7462 \\
\hline Latvia & 3.2370 & 23.7755 & 12.1965 & 8.1950 & 0.5179 & 37.1669 & 18.8811 & 12.3706 \\
\hline Lithuania & 0.1824 & 30.5119 & 15.4894 & 10.4238 & 2.3816 & 29.6871 & 15.8014 & 10.7737 \\
\hline Poland & 4.9238 & 48.5862 & 25.8412 & 17.9884 & 1.4323 & 40.4925 & 22.3914 & 15.3243 \\
\hline Romania & 2.2956 & 29.4947 & 16.6234 & 11.4730 & 0.2762 & 47.2754 & 24.9916 & 17.5495 \\
\hline Slovakia & 3.4114 & 48.2462 & 24.2063 & 16.9555 & 0.4606 & 44.7273 & 23.7293 & 16.2438 \\
\hline Slovenia & 4.6394 & 31.7152 & 16.2565 & 11.3121 & 0.5743 & 33.5498 & 17.9570 & 12.3690 \\
\hline
\end{tabular}


Table 8. Causality analysis between renewable energy and $\mathrm{CO}_{2}$ emissions.

\begin{tabular}{|c|c|c|c|c|c|c|c|c|}
\hline \multirow{3}{*}{ Countries } & \multicolumn{4}{|c|}{$\mathrm{H}_{0}: \mathrm{CO}_{2}$ Emission Is Not the Cause of RNW } & \multicolumn{4}{|c|}{$\mathrm{H}_{0}$ : RNW Is Not the Cause of $\mathrm{CO}_{2}$ Emission } \\
\hline & \multirow{2}{*}{ Wald St. } & \multicolumn{3}{|c|}{ Bootstrap Critic Value } & \multirow{2}{*}{ Wald St. } & \multicolumn{3}{|c|}{ Bootstrap Critic Value } \\
\hline & & $1 \%$ & $5 \%$ & $10 \%$ & & $1 \%$ & $5 \%$ & $10 \%$ \\
\hline Bulgaria & 4.2209 & 28.3144 & 14.5398 & 9.6870 & 4.1849 & 27.78286 & 14.6908 & 0.1074 \\
\hline Croatia & 2.3197 & 38.3059 & 20.2272 & 13.7559 & 0.5236 & 42.24757 & 20.1602 & 13.2400 \\
\hline Czechia & 5.6996 & 34.8510 & 17.9577 & 12.1791 & $78.5323 * * *$ & 37.90574 & 21.2318 & 14.4659 \\
\hline Estonia & 2.9785 & 30.7269 & 16.0333 & 10.4784 & 4.7461 & 30.11468 & 14.8927 & 9.8172 \\
\hline Hungary & 1.5115 & 51.1984 & 26.7677 & 18.3740 & $16.4136^{*}$ & 44.07672 & 23.8917 & 16.3845 \\
\hline Latvia & 0.6672 & 29.4360 & 14.8573 & 9.6784 & 12.9507 * & 36.25140 & 19.0939 & 12.5903 \\
\hline Lithuania & $14.4073^{* *}$ & 26.7428 & 13.3773 & 8.7281 & 2.7378 & 28.31456 & 15.3157 & 10.0500 \\
\hline Poland & 0.33374 & 28.9642 & 15.0131 & 10.1679 & 3.6145 & 43.67226 & 22.8993 & 15.7815 \\
\hline Romania & $17.2924^{* *}$ & 27.7321 & 14.0219 & 9.7921 & $33.5551 * *$ & 38.07972 & 20.0294 & 13.6791 \\
\hline Slovakia & $22.0571 *$ & 43.8053 & 22.5734 & 15.8978 & $19.4469 *$ & 39.57048 & 23.2065 & 16.4650 \\
\hline Slovenia & $12.2983 *$ & 32.5947 & 17.6888 & 11.5974 & 10.4034 & 44.19843 & 22.9981 & 16.2071 \\
\hline
\end{tabular}

$* * *, * * * *$ indicates that it is respectively significant at $1 \%, 5 \%, 10 \%$.

Table 9. Causality analysis between real GDP per capita and renewable energy.

\begin{tabular}{|c|c|c|c|c|c|c|c|c|}
\hline \multirow{3}{*}{ Countries } & \multicolumn{4}{|c|}{$\mathrm{H}_{0}$ : GDP Is Not the Cause of RNW } & \multicolumn{4}{|c|}{$\mathrm{H}_{0}:$ RNW Is Not the Cause of GDP } \\
\hline & \multirow{2}{*}{ Wald St. } & \multicolumn{3}{|c|}{ Bootstrap Critic Value } & \multirow{2}{*}{ Wald St. } & \multicolumn{3}{|c|}{ Bootstrap Critic Value } \\
\hline & & $1 \%$ & $5 \%$ & $10 \%$ & & $1 \%$ & $5 \%$ & $10 \%$ \\
\hline Bulgaria & 2.0464 & 50.8993 & 29.1946 & 20.1993 & 7.1154 & 53.3875 & 29.44463 & 20.8589 \\
\hline Croatia & 0.4233 & 35.0795 & 18.5855 & 12.2062 & 0.4570 & 45.3903 & 22.44310 & 14.7866 \\
\hline Czechia & $16.2285 *$ & 37.6513 & 22.2228 & 15.8881 & 6.3666 & 51.3260 & 26.75393 & 18.8187 \\
\hline Estonia & 3.4169 & 28.8198 & 14.9741 & 9.97130 & 10.5094 & 53.1987 & 28.49377 & 19.3129 \\
\hline Hungary & 5.9984 & 57.1728 & 32.3425 & 22.8146 & 5.3495 & 31.1988 & 17.01013 & 11.6173 \\
\hline Latvia & 4.6993 & 20.6217 & 10.4578 & 7.1282 & 0.8446 & 50.9055 & 25.71107 & 17.2067 \\
\hline Lithuania & 1.8078 & 52.7100 & 30.2212 & 21.8787 & 6.9219 & 62.2689 & 35.59382 & 25.7880 \\
\hline Poland & 24.0955 & 74.0902 & 43.6008 & 33.4240 & 2.8522 & 31.0150 & 15.81786 & 10.4976 \\
\hline Romania & $23.5227^{* *}$ & 34.1308 & 18.6578 & 12.8874 & 3.9612 & 49.2939 & 7.18408 & 18.5251 \\
\hline Slovakia & 16.0550 & 61.6467 & 35.6302 & 26.1593 & 10.8854 & 72.1978 & 39.51884 & 28.4645 \\
\hline Slovenia & $14.2667^{*}$ & 38.4524 & 19.4535 & 13.4619 & 0.4506 & 47.6993 & 24.63181 & 17.3053 \\
\hline
\end{tabular}

$* *,{ }^{*}$ indicates that it is respectively significant at $1 \%, 5 \%, 10 \%$.

The causality analysis between financial globalization and renewable energy presented in Table 7 revealed no significant causality between financial globalization and renewable energy. A significant causality from financial globalization to renewable energy is expected because it facilitates the countries to provide the funds in the international markets. Furthermore, Leitão [15] and Yazdi and Shakouri [16] revealed a reciprocal interaction between globalization and renewable energy.

The causality analysis between $\mathrm{CO}_{2}$ emissions and renewable energy presented in Table 8 a unilateral causality from $\mathrm{CO}_{2}$ emissions to renewable energy in Lithuania and Slovenia, and unilateral causality from renewable energy to $\mathrm{CO}_{2}$ emissions in Czechia, Hungary, and Latvia and a reciprocal causality between renewable energy to $\mathrm{CO}_{2}$ emissions in Romania and Slovakia. Theoretically, rising $\mathrm{CO}_{2}$ emissions is one of the countries' 
motivations to make renewable energy investments because renewable energy is a relatively more environmentally friendly energy type. Therefore, the use of renewable energy is expected to decrease $\mathrm{CO}_{2}$ emissions. In this context, a significant causality between renewable energy and $\mathrm{CO}_{2}$ emissions in Czechia, Hungary, Latvia, Romania, and Slovakia was compatible with the theoretical considerations and Jebli and Youssef [31], Tiba et al. [33], and Jebli et al. [20].

Lastly, the causality analysis between real GDP per capita and renewable energy introduced in Table 9 denoted a unilateral causality from real GDP per capita to renewable energy in Czechia, Romania, and Slovenia. A significant causality between real GDP per capita and renewable energy is expected because renewable energy development requires substantial investments, and increasing GDP raises the countries' energy requirement. However, significant causality from real GDP per capita to renewable energy was revealed for Czechia, Romania, and Slovenia incompatible with Jebli and Youssef [31], and Padhan et al. [17]. However, Sebri et al. [19], Jebli et al. [32], Yazdi and Shakouri [16], Amri [34], Rasoulinezhad and Saboori [9] revealed a mutual causality between economic growth and renewable energy consumption.

\section{Conclusions}

The serious environmental degradation and decreasing fossil fuel supplies have led policy-makers and scholars to seek alternative solutions for sustainable economic growth and the environment. In this context, renewable energy resources have become a critical option for decarbonization, together with the technological developments in renewable energy production and the countries head for renewable energy production. For example, the EU aims to meet $32 \%$ of energy requirements from renewable energy by 2030 to achieve the first climate-neutral continent by 2050. Therefore, the specification of the factors underlying renewable energy production has become crucial. In turn, determinants of renewable energy production/consumption have been extensively researched in the related literature. The scholars have generally reached conflicting findings of institutional and economic determinants of renewable energy production or consumption. However, the impact of economic globalization indicators on renewable energy has been explored by a limited number of scholars. Therefore, we researched the causality among economic globalization indicators, real GDP per capita, $\mathrm{CO}_{2}$ emissions, and renewable energy in a sample of EU transition economies through bootstrap panel Granger causality test of Kónya [12] taking notice of heterogeneity and cross-section independence among the series.

The causality analysis revealed that trade globalization significantly influenced renewable energy in Estonia, Latvia, and Slovenia, which experienced significant renewable energy production progress. Still, no significant causality between financial globalization and renewable energy was revealed. The relevant theoretical considerations and empirical findings indicated that both trade and financial globalization significantly influence renewable energy and, in turn, renewable energy has a significant influence on trade. On the other side, a unilateral causality from $\mathrm{CO}_{2}$ emissions to renewable energy was revealed in Lithuania and Slovenia, and unilateral causality from renewable energy to $\mathrm{CO}_{2}$ emissions was discovered in Czechia, Hungary, and Latvia and a mutual causality between renewable energy and $\mathrm{CO}_{2}$ emissions in Romania and Slovakia in compatible with relevant theoretical and empirical literature. Lastly, a unilateral causality from real GDP per capita to renewable energy in Czechia, Romania, and Slovenia was discovered.

The EU aims to meet 32\% of energy requirements from renewable energy by 2030. The Czechia, Hungary, Poland, and Slovakia in EU transition economies especially should make a significant improvement to catch the target. However, renewable energy production needs relatively high investments. Therefore, all the EU countries, especially the countries in the question above, should benefit from trade and financial globalization to improve renewable energy production through technology and financing transfer. Future studies can focus on the mechanisms through which trade and financial globalization affect renewable energy production. 
Author Contributions: All authors have contributed significantly to this research in all stages of the study. Conceptualization, Y.B., M.U.S., and M.H.O.; methodology, Y.B., M.U.S., and M.H.O.; formal analysis, Y.B., M.U.S., and M.H.O.; writing, Y.B., M.U.S., and M.H.O. All authors have read and agreed to the published version of the manuscript.

Funding: This research received no external funding.

Conflicts of Interest: The authors declare no conflict of interest.

\section{References}

1. Omer, A.M. Energy use and environmental impacts: A general review. J. Renew. Sustain. Energy 2009, 1, 53101. [CrossRef]

2. Bologna, S. Energy and Sustainable Economic Development. In Renewable Energy for Unleashing Sustainable Development; Colombo, E., Bologna, S., Masera, D., Eds.; Springer: Cham, Switzerland, 2013. [CrossRef]

3. Manisalidis, I.; Stavropoulou, E.; Stavropoulos, A.; Bezirtzoglou, E. Environmental and Health Impacts of Air Pollution: A Review. Front. Public Health 2020, 8, 14. [CrossRef] [PubMed]

4. IEA. Renewables. 2020. Available online: https://www.iea.org/fuels-and-technologies/renewables (accessed on 15 September 2020).

5. BP. Statistical Review of World Energy 2020 (69th Edition). 2020. Available online: https://www.bp.com/content/dam/ bp/business-sites/en/global/corporate/pdfs/energy-economics/statistical-review/bp-stats-review-2020-full-report.pdf (accessed on 15 September 2020).

6. Sadorsky, P. Renewable energy consumption, $\mathrm{CO}_{2}$ emissions and oil prices in the $\mathrm{G} 7$ countries. Energy Econ. 2009, 31, 456-462. [CrossRef]

7. Apergis, N.; Payne, J.E. The causal dynamics between renewable energy, real GDP, emissions and oil prices: Evidence from OECD countries. Appl. Econ. 2014, 46, 4519-4525. [CrossRef]

8. Ackah, I.; Kizys, R. Green growth in oil producing African countries: A panel data analysis of renewable energy demand. Renew. Sustain. Energy Rev. 2015, 50, 1157-1166. [CrossRef]

9. Rasoulinezhad, E.; Saboori, B. Panel estimation for renewable and non-renewable energy consumption, economic growth, $\mathrm{CO}_{2}$ emissions, the composite trade intensity, and financial openness of the commonwealth of independent states. Environ. Sci. Pollut. Res. 2018, 25, 17354-17370. [CrossRef]

10. Ergun, S.J.; Owusu, P.A.; Rivas, M.F. Determinants of renewable energy consumption in Africa. Environ. Sci. Pollut. Res. 2019, 26, 15390-15405. [CrossRef]

11. Chang, C.-L.; Ilomäki, J.; Laurila, H.; McAleer, M. Causality between $\mathrm{CO}_{2}$ Emissions and Stock Markets. Energies 2020, $13,2893$. [CrossRef]

12. Kónya, L. Exports and growth: Granger causality analysis on OECD countries with a panel data approach. Econ. Model. 2006, 23, 978-992. [CrossRef]

13. Eurostat. Share of Energy from Renewable Sources. 2020. Available online: https://ec.europa.eu/eurostat/databrowser/view/ nrg_ind_ren/default/table?lang=en (accessed on 12 August 2020).

14. World Bank. Renewable Energy Consumption (\% of Total Final Energy Consumption). 2020. Available online: https://data. worldbank.org/indicator/eg.fec.rnew.zs (accessed on 15 June 2020).

15. Leitão, N.C. Economic growth, carbon dioxide emissions, renewable energy and globalization. Int. J. Energy Econ. Policy 2014, 3, 391-399.

16. Yazdi, S.K.; Shakouri, B. The globalization, financial development, renewable energy, and economic growth. Energy Sources Part B Econ. Plan. Policy 2017, 12, 707-714. [CrossRef]

17. Padhan, H.; Padhang, P.C.; Tiwari, A.K.; Ahmed, R.; Hammoudeh, S. Renewable energy consumption and robust globalization(s) in OECD countries: Do oil, carbon emissions and economic activity matter? Energy Strat. Rev. 2020, 32, 100535. [CrossRef]

18. Gozgor, G.; Mahalik, M.K.; Demir, E.; Padhan, H. The impact of economic globalization on renewable energy in the OECD countries. Energy Policy 2020, 139, 111365. [CrossRef]

19. Sebri, M.; Ben-Salha, O. On the causal dynamics between economic growth, renewable energy consumption, $\mathrm{CO}_{2}$ emissions and trade openness: Fresh evidence from BRICS countries. Renew. Sustain. Energy Rev. 2014, 39, 14-23. [CrossRef]

20. Jebli, M.B.; Youssef, S.B.; Apergis, N. The dynamic linkage between renewable energy, tourism, $\mathrm{CO}_{2}$ emissions, economic growth, foreign direct investment, and trade. Latin Am. Econ. Rev. 2019, 28, 2-19. [CrossRef]

21. Zeren, F.; Akkuş, H.T. The relationship between renewable energy consumption and trade openness: New evidence from emerging economies. Renew. Energy 2020, 147, 322-329. [CrossRef]

22. Dumitrescu, E.; Hurlin, C. Testing for Granger non-causality in heterogeneous panels. Econ. Model. 2012, 29, 1450-1460. [CrossRef]

23. Murshed, M. Does Improvement in Trade Openness Facilitate Renewable Energy Transition? Evidence from Selected South Asian Economies. South Asia Econ. J. 2018, 19, 151-170. [CrossRef]

24. Akar, B.G. The Determinants of Renewable Energy Consumption: An Empirical Analysis for the Balkans. Eur. Sci. J. ESJ 2016, 12, 594. [CrossRef]

25. Alam, M.; Murad, W. The impacts of economic growth, trade openness and technological progress on renewable energy use in organization for economic co-operation and development countries. Renew. Energy 2020, 145, 382-390. [CrossRef] 
26. Lau, L.S.; Yii, K.J.; Lee, C.Y.; Chong, Y.L.; Lee, E.H. Investigating the determinants of renewable energy consumption in Malaysia: An ARDL approach. Int. J. Bus. Soc. 2018, 19, 886-903.

27. Kumaran, V.V.; Ridzuan, A.R.; Khan, F.U.; Abdullah, H.; Mohamad, Z.Z. An empirical analysis of factors affecting renewable energy consumption in association of Southeast Asian Nations-4 countries. Int. J. Energy Econ. Policy 2020, 10, 48-56. [CrossRef]

28. Zhao, P.; Lu, Z.; Fang, J.; Paramati, S.R.; Jiang, K. Determinants of renewable and non-renewable energy demand in China. Struct. Chang. Econ. Dyn. 2020, 54, 202-209. [CrossRef]

29. Aïssa, M.S.B.; Jebli, M.B.; Youssef, S.B. Output, renewable energy consumption and trade in Africa. Energy Policy 2014, 66, 11-18. [CrossRef]

30. Kim, K.; Kim, Y. Role of policy in innovation and international trade of renewable energy technology: Empirical study of solar PV and wind power technology. Renew. Sustain. Energy Rev. 2015, 44, 717-727. [CrossRef]

31. Jebli, M.B.; Youssef, S.B. The environmental Kuznets curve, economic growth, renewable and non-renewable energy, and trade in Tunisia. Renew. Sustain. Energy Rev. 2015, 47, 173-185. [CrossRef]

32. Jebli, M.B.; Youssef, S.B.; Ozturk, I. Testing environmental Kuznets curve hypothesis: The role of renewable and non-renewable energy consumption and trade in OECD countries. Ecol. Indic. 2016, 60, 824-831. [CrossRef]

33. Tiba, S.; Omri, A.; Frikha, M. The four-way linkages between renewable energy, environmental quality, trade and economic growth: A comparative analysis between high and middle-income countries. Energy Syst. 2016, 7, 103-144. [CrossRef]

34. Amri, F. Intercourse across economic growth, trade and renewable energy consumption in developing and developed countries. Renew. Sustain. Energy Rev. 2017, 69, 527-534. [CrossRef]

35. Liu, X.; Zhang, S.; Bae, J. Renewable energy, trade, and economic growth in the Asia-Pacific region. Energy Sources Part B Econ. Plan. Policy 2018, 13, 1-7. [CrossRef]

36. Nathaniel, S.; Khan, S.A.R. The nexus between urbanization, renewable energy, trade, and ecological footprint in ASEAN countries. J. Clean. Prod. 2020, 272, 122709. [CrossRef]

37. Alabi, O.; Ackah, I.; Lartey, A. Re-visiting the renewable energy-economic growth nexus: Empirical evidence from African OPEC countries. Int. J. Energy Sect. Manag. 2017, 11, 387-403. [CrossRef]

38. Caruso, G.; Colantonio, E.; Gattone, S.A. Relationships between Renewable Energy Consumption, Social Factors, and Health: A Panel Vector Auto Regression Analysis of a Cluster of 12 EU Countries. Sustainability 2020, 12, 2915. [CrossRef]

39. Menyah, K.; Wolde-Rufael, Y. $\mathrm{CO}_{2}$ emissions, nuclear energy, renewable energy and economic growth in the US. Energy Policy 2010, 38, 2911-2915. [CrossRef]

40. Ocal, O.; Aslan, A. Renewable energy consumption-economic growth nexus in Turkey. Renew. Sustain. Energy Rev. 2013, 28, 494-499. [CrossRef]

41. Bakirtaş, I.; Çetin, M.A. Yenilenebilir Enerji Tüketimi 'Ile Ekonomik Büyüme Arasındaki İlişkisi: G-20 Ülkeleri. Sosyoekonomi 2016, 24, 131-145. [CrossRef]

42. Lin, B.; Omoju, O.E.; Okonkwo, J.U. Factors influencing renewable electricity consumption in China. Renew. Sustain. Energy Rev. 2016, 55, 687-696. [CrossRef]

43. Przychodzen, W.; Przychodzen, J. Determinants of renewable energy production in transition economies: A panel data approach. Energy 2020, 191, 116583. [CrossRef]

44. Mehrara, M.; Rezaei, S.; Razi, D.H. Determinants of Renewable Energy Consumption among ECO Countries; Based on Bayesian Model Averaging and Weighted-Average Least Square. Int. Lett. Soc. Humanist. Sci. 2015, 54, 96-109. [CrossRef]

45. Omoju, O. Determinants of renewable energy development in China. In Proceedings of the 38th IAEE International Conference Energy Security, Technology and Sustainability Challenges Across the Globe, Antalya, Turkey, 25-27 May 2015.

46. Omri, A.; Nguyen, D.K. On the determinants of renewable energy consumption: International evidence. Energy 2014, 72, 554-560. [CrossRef]

47. Dogan, E.; Seker, F. Determinants of $\mathrm{CO}_{2}$ emissions in the European Union: The role of renewable and non-renewable energy. Renew. Energy 2016, 94, 429-439. [CrossRef]

48. Omri, A.; Daly, S.; Nguyen, D.K. A robust analysis of the relationship between renewable energy consumption and its main drivers. Appl. Econ. 2015, 47, 2913-2923. [CrossRef]

49. Paweenawat, S.W.; Plyngam, S. Does the causal relationship between renewable energy consumption, $\mathrm{CO}_{2}$ emissions, and economic growth exist in Thailand? An ARDL approach. Econ. Bull. 2017, 37, 697-711.

50. KOF Swiss Economic Institute. KOF Globalisation Index. 2020. Available online: https://kof.ethz.ch/en/forecasts-andindicators /indicators / kof-globalisation-index.html (accessed on 15 June 2020).

51. Gygli, S.; Haelg, F.; Potrafke, N.; Sturm, J.-E. The KOF Globalisation Index-Revisited. Rev. Int. Organ. 2019, 14, 543-574. [CrossRef]

52. World Bank. GDP Per Capita (Constant 2010 US\$). 2020. Available online: https:/ / data.worldbank.org/indicator/NY.GDP.PCAP. KD (accessed on 15 June 2020).

53. World Bank. CO2 Emissions (Metric Tons Per Capita). 2020. Available online: https://data.worldbank.org/indicator/EN.ATM. CO2E.PC (accessed on 15 June 2020).

54. O'Connell, P.G. The overvaluation of purchasing power parity. J. Int. Econ. 1998, 44, 1-19. [CrossRef]

55. Pesaran, M.H. Estimation and Inference in Large Heterogeneous Panels with a Multifactor Error Structure. Econometrica 2006, 74, 967-1012. [CrossRef] 
56. Zellner, A. An efficient method of estimating seemingly unrelated regressions and tests for aggregation bias. J. Am. Stat. Assoc. 1962, 57, 348-368. [CrossRef]

57. Granger, C.W.J. Some aspects of causal relationships. J. Econ. 2003, 112, 69-71. [CrossRef]

58. Breitung, J. A Parametric approach to the Estimation of Cointegration Vectors in Panel Data. Econ. Rev. 2005, 24, 151-173. [CrossRef]

59. Breusch, T.; Pagan, A. The Lagrange Multiplier Test and its Applications to Model Specification in Econometrics. Rev. Econ. Stud. 1980, 47, 239-253. [CrossRef]

60. Pesaran, M.H. General Diagnostic Tests for Cross-Sectional Dependence in Panels. CESinfo Work. Pap. 2004, 1229. Available online: https://ideas.repec.org/p/ces/ceswps/_1229.html (accessed on 10 April 2020). [CrossRef]

61. Pesaran, M.H.; Ullah, A.; Yamagata, T. A bias-adjusted LM test of error cross-section independence. Econ. J. 2008, 11, 105-127. [CrossRef]

62. Pesaran, M.H.; Yamagata, T. Testing slope homogeneity in large panels. J. Econ. 2008, 142, 50-93. [CrossRef] 